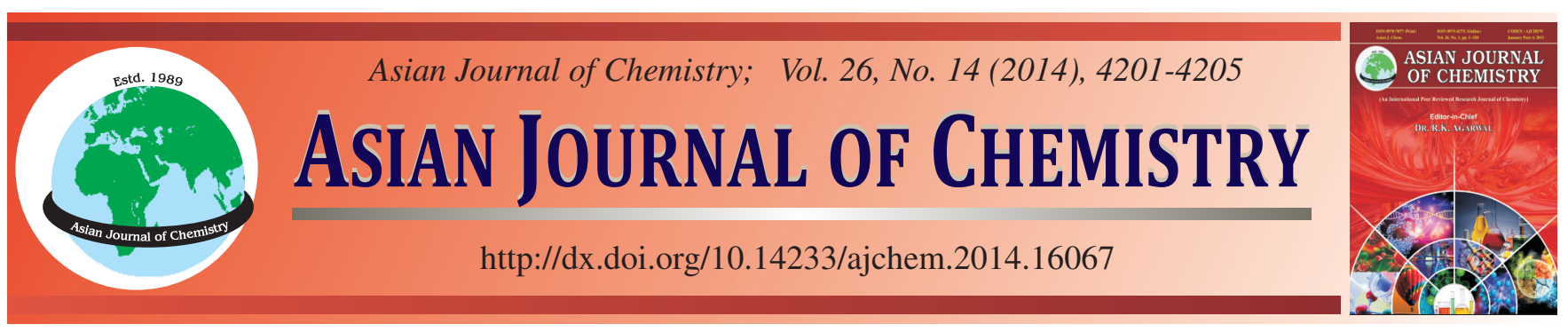

\title{
Chemical Composition, in vitro Cytotoxic and Antioxidant Activities of the Fruit Essential Oil of Alpinia oxyphylla
}

\author{
Chengzhong Wang, Huinui Yuan ${ }^{*}$, Xiaoli Bao and Minbo Lan ${ }^{*}$
}

Shanghai Key Laboratory of Functional Materials Chemistry and Research Center of Analysis and Test, East China University of Science and Technology, Shanghai 200237, P.R. China

*Corresponding authors: Tel: +86 21 64252969; E-mail: yuanhuihui@ecust.edu.cn (Huihui Yuan)

Fax: +86 21 64252947; Tel: +86 21 64253574; E-mail: minbolan@ecust.edu.cn (Minbo Lan)

\begin{abstract}
The aim of this study was to investigate in vitro cytotoxic and antioxidant activities of the fruit essential oil of Alpinia oxyphylla. The essential oil obtained by hydrodistillation was analyzed by GC and GC-MS. Seventy-four constituents were identified, of which valencene $(19.04 \mathrm{~g} / 100 \mathrm{~g})$, calamenene $(10.11 \mathrm{~g} / 100 \mathrm{~g})$ and nootkatone $(8.97 \mathrm{~g} / 100 \mathrm{~g})$ were the main components. In vitro cytotoxicity of the oil on six human cancer cell lines was examined by Sulphorhodamine-B assay. The oil was very active against all tested cancer cell lines with the $\mathrm{IC}_{50}$ values ranging from 31.6 to $47.2 \mu \mathrm{g} / \mathrm{mL}$. Antioxidant activity of the oil was determined by $\mathrm{DPPH}^{\bullet}$ and reducing power assay. The essential oil exhibited good reducing power in a dose-dependent manner and strong DPPH radical scavenging activity with $\mathrm{IC}_{50}$ value of $140.7 \mu \mathrm{g} / \mathrm{mL}$. Our findings suggested that the essential oil could hold a good potential for use in food and pharmaceutical industry.
\end{abstract}

Keywords: Alpinia oxyphylla, Essential oil, Antioxidant activity, Cytotoxicity, Composition.

\section{INTRODUCTION}

Essential oils extracted from plants have gained special attention since ancient times owing to their pleasant fragrances and multiple functions and nowadays have been extensively used in food, perfumery, cosmetics and winery industries. In recent decades, essential oils and their components have been found and developed various officinal values including antibacterial $^{1,2}$, antiviral ${ }^{2}$, antiinflammatory ${ }^{3}$, antifungal ${ }^{4}$, antimutagenic $^{5}$, anticancer ${ }^{6-9}$ and antioxidant ${ }^{10-12}$, as well as other miscellaneous activities. Therefore, increasing focus is being placed on the plant essential oils for seeking natural and safe alternative food preservations and medicines due to their multiple bioactivities, especially their antioxidant and anticancer activities ${ }^{13}$.

Alpinia oxyphylla Miquel (Zingiberaceae), widely distributed in South China, is an important medicinal herb in Chinese traditional medicine. The fruits of this plant have been used as a folk medicine for the treatment of intestinal disorders, urosis, diuresis, ulceration and dementia and were officially listed in Chinese Pharmacopeia ${ }^{14}$. Previous phytochemical and biological investigations of this plant have reported the isolation of diterpenes, flavonoids, diarylheptanoids and sesquiterpenoids ${ }^{15-17}$. Alpinia oxyphylla fruit has also been reported to possess antianaphylactic ${ }^{18}$, antitumor ${ }^{19,20}$ and neuroprotec- tive $^{21,22}$. As an important natural product of this plant, the fruit essential oil of Alpinia oxyphylla has been officially assigned as the most important factor to evaluate and control the quality of Alpinia oxyphylla in China Pharmacopeia ${ }^{14}$. To date, there are quite few available reports on biological properties of the fruit essential oil of Alpinia oxyphylla, although several studies have been published concerning the chemical analysis of the $\mathrm{oil}^{23,24}$. Therefore, the aim of the present work was to study in vitro cytotoxic and antioxidant activities of the essential oil in addition to evaluate its components. To the best of our knowledge, this is the first study of the cytotoxic and antioxidant activities of the fruit essential oil of Alpinia oxyphylla.

\section{EXPERIMENTAL}

A mixture of $n$-alkanes $\left(\mathrm{C}_{6}-\mathrm{C}_{20}\right)$ used for determination of retention indices was purchased from Supelco (Bellefonte, PA, USA). The standard volatile compounds used to measure correction factors and validate the compounds of the essential oil, $\mathrm{DPPH}^{\circ}$, Sulforhodamine B and 5-fluorouracil obtained from Sigma-Aldrich (St. Louis, MO, USA). All other chemicals were of analytical grade and obtained from Sinopharm Chemical Reagent Co. (Shanghai, China).

The air-dried fruits of Alpinia oxyphylla were collected from Guangxi Province, People's Republic of China, in October 2010. The voucher specimen (No. 11010) was authenticated 
by Prof. Yongchuan Zhou (from East China University of Science and Technology) and deposited at the herbarium of Research Center of Analysis and Test, East China University of Science and Technology, China.

Essential oil extraction: The dried and powered fruits of Alpinia oxyphylla (200 g) were subject to hydrodistillation for $4 \mathrm{~h}$ using a Clevenger type apparatus for essential oil extraction. The essential oils were collected, dried over anhydrous sodium sulphate and stored in sealed vials protected from the light at $-20{ }^{\circ} \mathrm{C}$ before analyses.

GC and GC-MS analysis: GC analysis was carried out using a Hewlett-packard 6890 gas chromatograph equipped with a fused silica capillary column DB-5MS (5\% phenylmethylsiloxane, $30 \mathrm{~m} \times 0.25 \mathrm{~mm}$, film thickness $0.25 \mu \mathrm{m}$, Agilent Technologies, USA). The column oven temperature was programmed to rise from an initial temperature of 40 to $250{ }^{\circ} \mathrm{C}$ at a ratio of $4{ }^{\circ} \mathrm{C} / \mathrm{min}$ and maintained at $250{ }^{\circ} \mathrm{C}$ for $5 \mathrm{~min}$. Split injection mode with a split ratio of 1:50 was employed. Quantification of components in the oil were obtained based on the GC peak areas, using both the internal standard method and relative response factors as described in literature ${ }^{25}$. GCMS analysis was performed on a Hewlett-packard 6890 gas chromatograph, coupled with a Hewlett-Packard mass-selective detector 5973N quadropole mass spectrometer (Agilent Technologies, CA, USA). All the GC experimental parameters were the same as described for GC-FID analysis. The mass spectrometer (MS) was operated in the electron impact ionization (EI) mode with the ionization energy of $70 \mathrm{eV}$. The temperatures of MS source and MS quadruple were 230 and $150{ }^{\circ} \mathrm{C}$, respectively. Identification of the oil components was performed by comparison of their mass spectra and linear retention indices with those stored in Wiley/NIST mass spectral library, as well as authentic standards and literatures ${ }^{26,27}$.

Cytotoxic activity: Human breast cancer cell line (MCF7), human cervix carcinoma cell line (HeLa), human liver carcinoma cell line (HepG2), human gastric cancer cell line (MNK-45), human lung adenocarcinoma cell line (A549) and human colon cancer cell line (SW480) were obtained from China Center for Type Culture Collection. The effects of the essential oil on inhibition of cell growth were measured by the SRB (Sulforhodamine B) assay. The SRB growth inhibition assay was performed as the procedure described previously ${ }^{28}$. Briefly, after being harvested from culture flasks, the cells (1 $\times 10^{4}$ ) were seeded in each well of a 96-well plate containing $100 \mu \mathrm{L}$ fresh growth medium per well and permitted to adhere for $24 \mathrm{~h}$. The cells were treated with $200 \mu \mathrm{L}$ of different concentrations $(12.5-200 \mu \mathrm{g} / \mathrm{mL})$ of essential oils per well, respectively. After $48 \mathrm{~h}$ of treatment, the cells were fixed with $10 \%$ trichloroacetic acid (TCA) and stained with $100 \mu \mathrm{L}$ of SRB solution in $1 \%$ acetic acid for $15 \mathrm{~min}$. Unbound dye was removed by washing with $1 \%$ acetic acid. The bound dye was extracted with $10 \mathrm{mM}$ Tris- $\mathrm{HCl}$ for determination of optical density (OD) at $492 \mathrm{~nm}$ in a 96-well microtiter plate reader. Cytotoxicity was expressed as the concentration of oil or compound inhibiting cell growth by $50 \%$ (IC50). 5-FU was used as a positive control. All tests and analyses were run in triplicate.

Antioxidant activity: The scavenging activity of the essential oil on 2,2-diphenyl-1-picrylhydrazyl (DPPH ${ }^{\bullet}$ ) was measured as described previously ${ }^{29}$. Briefly, $2 \mathrm{~mL}$ of various concentrations of the essential oil solution (in methanol) were added to $2 \mathrm{~mL}$ of $0.1 \mathrm{mM} \mathrm{DPPH}^{\bullet}$ solution (in methanol). The solutions were mixed vigorously and incubated at room temperature for $0.5 \mathrm{~h}$ in the dark. The absorbance of the solutions, including a blank (containing all reagents except the sample) and a positive control (tert-butylated hydroxytoluene, BHT) was record at $517 \mathrm{~nm}$. The antioxidant capacity of the essential oil to scavenging DPPH radical was calculated by the following equation:

DPPH radical scavenging activity $(\%)=\left(1-\frac{\mathrm{A}_{\text {Sample }}}{\mathrm{A}_{\text {Blank }}}\right) \times 100$

where $\mathrm{A}_{\text {sample }}$ and $\mathrm{A}_{\text {blank }}$ are absorbance of sample and blank. $\mathrm{IC}_{50}$ value calculated denotes the concentration of sample required to decrease the absorbance at $517 \mathrm{~nm}$ by $50 \%$. All tests were carried out in triplicate.

The reducing power of the essential oil was determined according to the method of Oyaizu ${ }^{30}$. Different concentrations $(100-500 \mu \mathrm{g} / \mathrm{mL})$ of essential oil in methanol $(2.5 \mathrm{~mL})$ was mixed with $2.5 \mathrm{~mL}$ of phosphate buffer $(0.2 \mathrm{~mol} / \mathrm{L}, \mathrm{pH} 6.6)$ and $2.5 \mathrm{~mL}$ of potassium ferricyanide $(1 \%, \mathrm{w} / \mathrm{v})$. The mixture was incubated at $50{ }^{\circ} \mathrm{C}$ for $20 \mathrm{~min}$. Then, $2.5 \mathrm{~mL}$ of trichloroacetic acid $(10 \%, \mathrm{w} / \mathrm{v})$ was added and the mixture was centrifuged at $3000 \mathrm{rpm}$ for $10 \mathrm{~min}$. The upper layer of solution $(2.5 \mathrm{~mL}$ ) was mixed with $2.5 \mathrm{~mL}$ of deionized water and $0.5 \mathrm{~mL}$ of ferric chloride $(0.1 \%, w / v)$. Finally the absorbance was measured at $700 \mathrm{~nm}$ against a blank. BHT was used as a positive control. All tests and analyses were run in triplicate.

\section{RESULTS AND DISCUSSION}

Chemical composition of essential oil: The essential oil was obtained by hydrodistillation from the fruits of Alpinia oxyphylla with the yield of $0.9 \%(\mathrm{v} / \mathrm{w})$ on a dry weight basis. The chemical components of the essential oil were analyzed by GC and GC-MS with DB-5MS column. Qualitative and quantitative analytical results of the components are listed in Table-1. Quantification of analytes was carried out by the internal standard method and use of response factors and expressed in terms of both $\mathrm{g} / 100 \mathrm{~g}$ and \% peak areas.

Seventy-four compounds representing $83.91 \mathrm{~g} / 100 \mathrm{~g}$ of the oil were identified. The essential oil consisted mainly of sesquiterpene hydrocarbons $(56.21 \mathrm{~g} / 100 \mathrm{~g})$ and oxygenated sesquiterpenes $(25.20 \mathrm{~g} / 100 \mathrm{~g})$, as shown in Table-1. Valencene (19.04 g/100 g), calamenene(10.11 g/100 g), $\beta$-caryophyllene (5.56 g/100 g), $\alpha$-panasinsen (4.88 g/100 g) and $\alpha$-selinene $(4.02 \mathrm{~g} / 100 \mathrm{~g})$ were the main sesquiterpene hydrocarbons, while nootkatone $(8.97 \mathrm{~g} / 100 \mathrm{~g})$, caryophyllene oxide (2.11 $\mathrm{g} / 100 \mathrm{~g})$ and humulene epoxide II $(2.06 \mathrm{~g} / 100 \mathrm{~g})$ were found to be the major oxygenated sesquiterpenes. The monoterpene hydrocarbons only accounted for $0.70 \mathrm{~g} / 100 \mathrm{~g}$ of the oil, with $\alpha$-pinene $(0.14 \mathrm{~g} / 100 \mathrm{~g})$ and $\gamma$-terpinene $(0.10 \mathrm{~g} / 100 \mathrm{~g})$ as the main compounds. The oxygenated monoterpenes constituted $0.98 \mathrm{~g} / 100 \mathrm{~g}$ of the oil, with terpinene-4-ol $(0.42 \mathrm{~g} / 100 \mathrm{~g})$ and linalool $(0.26 \mathrm{~g} / 100 \mathrm{~g})$ as the main components.

The quantitative results (Table-1) of compounds were also expressed as \% peak areas to facilitate comparison with data reported in the literature. The components of the essential oil 


\begin{tabular}{|c|c|c|c|c|c|c|}
\hline & & $\begin{array}{r}\text { CHEM } \\
\text { ESS }\end{array}$ & $\begin{array}{l}\text { AL CO } \\
\text { NTIAL }\end{array}$ & $\begin{array}{l}\text { TABLE-1 } \\
\text { MPONENTS OF THE } \\
\text { OIL OF Alpinia oxyphy }\end{array}$ & & \\
\hline NO & $\mathrm{P}^{\mathrm{a}}$ & $\mathrm{P}^{\mathrm{b}}$ & PPFc & Comnounds & Perce & ntage \\
\hline NU. & KI & $\pi$ & Ккг & Compounus & $\mathrm{g} \%{ }^{\mathrm{d}}$ & $\% \mathrm{~A}^{\mathrm{e}}$ \\
\hline 1 & 925 & 924 & 1.20 & $\alpha$-Thujene & 0.03 & 0.05 \\
\hline 2 & 936 & 933 & 1.20 & $\alpha$-Pinene & 0.14 & 0.23 \\
\hline 3 & 944 & 944 & 1.20 & Camphene & 0.04 & 0.07 \\
\hline 4 & 973 & 973 & 1.20 & $\beta$-Pinene & 0.03 & 0.05 \\
\hline 5 & 987 & 987 & 1.20 & $\beta$-Myrcene & 0.02 & 0.03 \\
\hline 6 & 1003 & 1003 & 1.20 & $\alpha$-Phellandrene & 0.01 & 0.02 \\
\hline 7 & 1009 & 1006 & 1.20 & $\delta$-3-Carene & 0.02 & 0.04 \\
\hline 8 & 1013 & 1013 & 1.20 & $\alpha$-Terpinene & 0.06 & 0.11 \\
\hline 9 & 1022 & 1022 & 1.36 & $p$-Cymene & 0.05 & 0.06 \\
\hline 10 & 1026 & 1026 & 1.20 & Limonene & 0.06 & 0.09 \\
\hline 11 & 1027 & 1027 & 1.20 & $\beta$-Phellandrene & 0.06 & 0.08 \\
\hline 12 & 1031 & 1029 & 1.34 & Eucalyptol & 0.04 & 0.04 \\
\hline 13 & 1033 & 1033 & 1.20 & cis- $\beta$-Ocimene & 0.02 & 0.04 \\
\hline 14 & 1043 & 1043 & 1.20 & trans- $\beta$-Ocimene & 0.06 & 0.11 \\
\hline 15 & 1054 & 1054 & 1.20 & $\gamma$-Terpinene & 0.10 & 0.17 \\
\hline 16 & 1065 & 1066 & 1.36 & Acetophenone & 0.48 & 0.49 \\
\hline 17 & 1098 & 1098 & 1.34 & Linalool & 0.26 & 0.26 \\
\hline 18 & 1135 & 1132 & 1.37 & Nopinone & 0.07 & 0.06 \\
\hline 19 & 1178 & 1178 & 1.34 & Terpinene-4-ol & 0.42 & 0.38 \\
\hline 20 & 1185 & 1181 & 1.25 & Melilotal & 0.03 & 0.05 \\
\hline 21 & 1188 & 1189 & 1.34 & $\alpha$-Terpinol & 0.10 & 0.10 \\
\hline 22 & 1191 & 1191 & 1.25 & Myrtenal & 0.06 & 0.08 \\
\hline 23 & 1293 & 1290 & 1.36 & Thymol & 0.34 & 0.30 \\
\hline 24 & 1356 & 1356 & 1.15 & $\alpha$-Cubebene & 0.04 & 0.06 \\
\hline 25 & 1366 & 1366 & 1.15 & Cyclosativene & 0.18 & 0.27 \\
\hline 26 & 1374 & 1374 & 1.15 & Copaene & 1.17 & 1.26 \\
\hline 27 & 1382 & 1382 & 1.15 & $\beta$-Bourbobene & 0.39 & 0.47 \\
\hline 28 & 1386 & 1386 & 1.15 & $\beta$-Cubebene & 0.27 & 0.33 \\
\hline 29 & 1387 & 1387 & 1.15 & $\beta$-Elemene & 0.09 & 0.12 \\
\hline 30 & 1395 & 1395 & 1.15 & $\alpha$-Longifolene & 0.18 & 0.24 \\
\hline 31 & 1400 & 1400 & 1.15 & $\alpha$-Cedrene & 0.44 & 0.57 \\
\hline 32 & 1403 & 1403 & 1.15 & $\alpha$-Gurjunene & 0.06 & 0.10 \\
\hline 33 & 1418 & 1418 & 1.15 & $\beta$-Caryophyllene & 5.56 & 6.34 \\
\hline 34 & 1428 & 1428 & 1.15 & $\beta$-Gurjunene & 0.04 & 0.06 \\
\hline 35 & 1448 & 1452 & 1.15 & $\beta$-Humulene & 2.82 & 3.45 \\
\hline 36 & 1454 & 1454 & 1.15 & $\alpha$-Caryophyllene & 0.12 & 0.22 \\
\hline 37 & 1457 & 1455 & 1.15 & $\alpha$-Humulene & 0.49 & 0.73 \\
\hline 38 & 1468 & 1468 & 1.15 & Alloaromadendrene & 0.36 & 0.55 \\
\hline 39 & 1469 & 1469 & 1.15 & $\gamma$-Gurjunene & 0.12 & 0.18 \\
\hline 40 & 1472 & 1472 & 1.15 & $\gamma$-Selinene & 0.12 & 0.17 \\
\hline 41 & 1476 & 1476 & 1.15 & $\gamma$-Muurolene & 0.66 & 0.78 \\
\hline 42 & 1482 & 1482 & 1.15 & $\alpha$-Curcumene & 0.34 & 0.49 \\
\hline 43 & 1483 & 1483 & 1.15 & $\alpha$-Amorphene & 0.51 & 0.65 \\
\hline 44 & 1486 & 1486 & 1.15 & Eremophilene & 0.09 & 0.12 \\
\hline 45 & 1488 & 1488 & 1.15 & $\beta$-Selinene & 0.06 & 0.09 \\
\hline 46 & 1489 & 1489 & 1.15 & $(3 Z, 6 E)-\alpha-$ Farnesene & 0.12 & 0.22 \\
\hline 47 & 1490 & 1490 & 1.15 & $\alpha$-Zingiberene & 0.21 & 0.28 \\
\hline 48 & 1492 & 1492 & 1.15 & Bicyclogermacrene & 0.18 & 0.22 \\
\hline 49 & 1494 & 1494 & 1.15 & $\alpha$-Selinene & 4.02 & 4.65 \\
\hline 50 & 1495 & 1491 & 1.15 & Valencene & 19.04 & 20.56 \\
\hline 51 & 1507 & 1507 & 1.15 & $\beta$-Bisabonlene & 0.62 & 0.74 \\
\hline 52 & 1509 & 1509 & 1.15 & $\beta$-Himachalene & 0.77 & 0.96 \\
\hline 53 & 1517 & 1517 & 1.15 & $\delta$-Cadinene & 0.29 & 0.40 \\
\hline 54 & 1523 & 1523 & 1.15 & $\beta$-Sesquiphellandrene & 0.27 & 0.37 \\
\hline 55 & 1528 & 1528 & 1.15 & Calamenene & 10.11 & 12.32 \\
\hline 56 & 1533 & 1530 & 1.15 & $\alpha$-Panasinsen & 4.88 & 5.58 \\
\hline 57 & 1539 & 1539 & 1.15 & $\alpha$-Calacorene & 1.59 & 2.01 \\
\hline 58 & 1553 & 1549 & 1.30 & Elemol & 0.28 & 0.35 \\
\hline
\end{tabular}

\begin{tabular}{|c|c|c|c|c|c|c|}
\hline 59 & 1563 & 1563 & 1.30 & trans-Nerolidol & 1.01 & 1.22 \\
\hline 60 & 1575 & 1575 & 1.30 & Spathulenol & 0.96 & 1.03 \\
\hline 61 & 1580 & 1580 & 1.34 & Caryophyllene oxide & 2.11 & 2.21 \\
\hline 62 & 1584 & 1584 & 1.30 & Globulol & 0.45 & 0.55 \\
\hline 63 & 1592 & 1592 & 1.30 & Viridiflorol & 1.50 & 1.58 \\
\hline 64 & 1598 & 1598 & 0.81 & cis- $\beta$-Elemenone & 0.38 & 0.56 \\
\hline 65 & 1604 & 1606 & 1.34 & Humulene epoxide II & 2.06 & 2.14 \\
\hline 66 & 1612 & 1612 & 1.30 & 5-epi-Neointermedeol & 0.80 & 0.87 \\
\hline 67 & 1633 & 1633 & 1.30 & $\gamma$-Eudesmol & 0.57 & 0.69 \\
\hline 68 & 1642 & 1641 & 1.34 & Alloaromadendrene oxide & 0.85 & 0.93 \\
\hline 69 & 1657 & 1657 & 1.30 & $\beta$-Eudesmol & 1.16 & 1.23 \\
\hline 70 & 1661 & 1659 & 1.30 & $\alpha$-Cadinol & 1.24 & 1.37 \\
\hline 71 & 1709 & 1702 & 0.81 & 4-epi-Nootkatone & 1.22 & 1.79 \\
\hline 72 & 1746 & 1752 & 0.81 & $\alpha$-Cyperone & 0.54 & 0.73 \\
\hline 73 & 1758 & 1757 & 0.81 & Aristolone & 1.10 & 1.58 \\
\hline 74 & 1813 & 1802 & 0.81 & Nootkatone & 8.97 & 10.03 \\
\hline \multicolumn{5}{|c|}{ Total identified } & 83.91 & 97.03 \\
\hline \multicolumn{5}{|c|}{ Monoterpene hydrocarbons } & 0.70 & 1.15 \\
\hline & & & \multicolumn{2}{|c|}{ Oxygenated monoterpenes } & 0.98 & 0.97 \\
\hline & & & \multicolumn{2}{|c|}{ Sesquiterpene hydrocarbons } & 56.21 & 65.56 \\
\hline & & & \multicolumn{2}{|c|}{ Oxygenated sesquiterpenes } & 25.20 & 28.56 \\
\hline & & & \multicolumn{2}{|c|}{ Others } & 0.82 & 0.79 \\
\hline
\end{tabular}

${ }^{a}$ Retention indices relative to $n$-alkanes $\left(\mathrm{C}_{6}-\mathrm{C}_{20}\right)$ on the DB-5MS column; ${ }^{\mathrm{b}}$ Retention indices reported in the literature; ${ }^{\mathrm{c}}$ Relative response factor; ${ }^{\mathrm{d}} \mathrm{g} / 100 \mathrm{~g}$ essential oil; ${ }^{\mathrm{C}}$ Percentage peak area

in present study had a composition similar to previous reports ${ }^{22,23}$, but there were significant differences in the relative quantities of individual compounds. Luo et al. ${ }^{23}$ reported $p$ cymene $(44.87 \%)$, valencene $(9.13 \%)$, linalool ( $4.39 \%)$ and myrtenal $(3.90 \%)$ as the main components in fruit essential oil of Alpinia oxyphylla, while the contents of $p$-cymene $(0.06 \%)$, linaool $(0.26 \%)$ and myrtenal $(0.08 \%)$ were much lower in our research. Li et al. ${ }^{24}$ found valencene $(18.32 \%)$, $\alpha$-panasinsene $(8.40 \%)$ and intermedeol $(4.99 \%)$ to be major ones. However, intermedeol was not detected in this work; on the other hand, calamenene was a major component of the oil $(12.32 \%)$ here, but it was not found or in a much lower amount in previous literature ${ }^{23,24}$. These differences might have been derived from climatic, seasonal, geographical or chemtype factors.

Cytotoxic activity: To investigate the cytotoxic activity of Alpinia oxyphylla essential oil, we evaluated its effect on a selection of human cancer cell lines including A549 (human lung carcinoma), HepG2 (human liver carcinoma), SW480 (human colon carcinoma), Hela (human cervical carcinoma), MCF-7 (human breast carcinoma) and MNK-45 (human gastric carcinoma) cell lines by Sulphorhodaine-B assay. All cell lines were submitted to growing concentrations of the essential oil for $48 \mathrm{~h}$ and the cell viability of six human cancer cell lines were shown in Fig. 1. The Alpinia oxyphylla fruit essential oil was active against all six human cancer cell lines tested. It induced a significant concentration-dependent inhibitory effect on all six cancer cell lines in the dilutions ranging from 12.5 to $200 \mu \mathrm{g} / \mathrm{mL}$. As shown in Table-2, the $\mathrm{IC}_{50}$ values of the oil were 31.6, 33.6, 37.3, 42.8, 43.4 and $47.2 \mu \mathrm{g} / \mathrm{mL}$ for HepG2, HeLa, A549, MCF-7, MNK-45 and SW480, respectively. The $\mathrm{IC}_{50}$ values also indicated that the essential oil possessed significant cytotoxicity against all the tested cancer cell lines. Among the tested human cancer cell lines, three cancer cell lines (HepG2, HeLa and A549) was found to 
be more sensitive to the essential oil than the other three cell lines (MCF-7, MNK-45 and SW480) at the lower concentrations. Interestingly, the essential oil was more active against HepG2, A549, HeLa and SW480 than standard 5-fluorouracil, while MCF-7 and MNK-45 was found to be more sensitive to 5-fluorouracil than the fruit essential oil of Alpinia oxyphylla (Table-2).

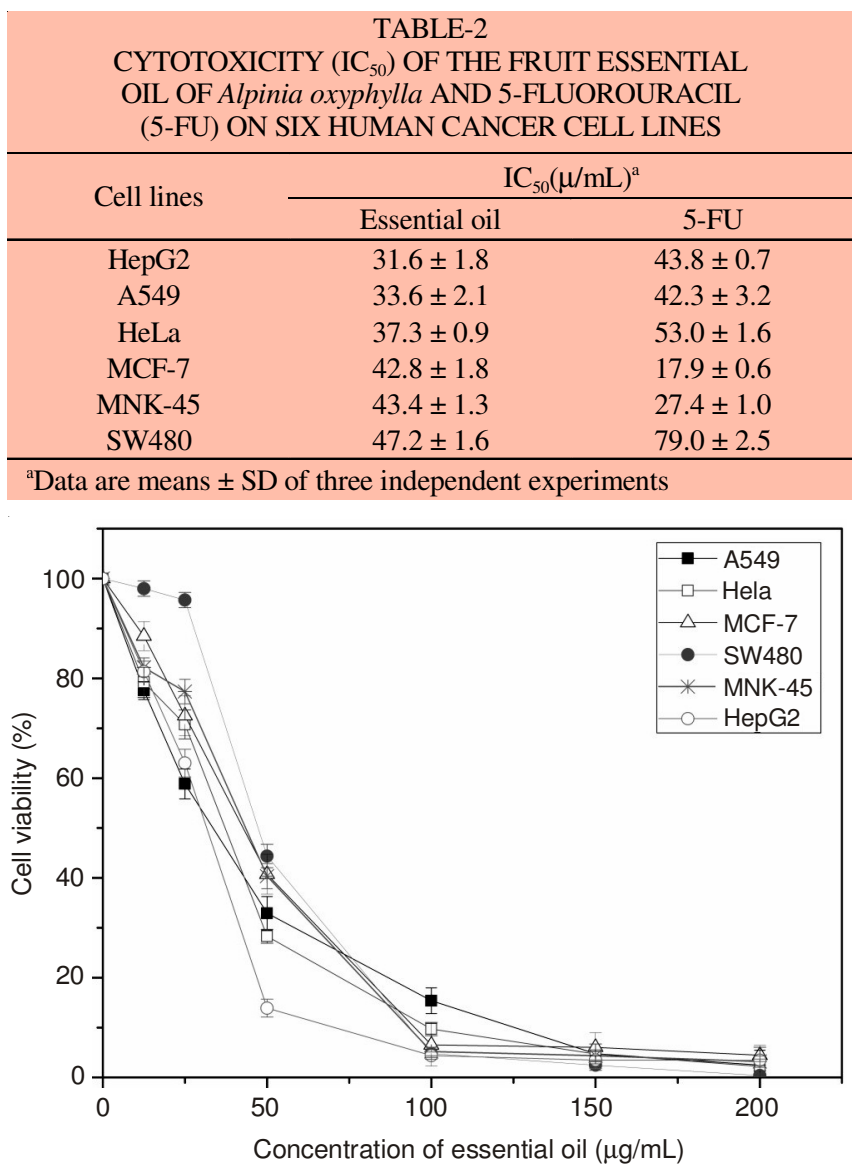

Fig. 1. Cytotoxic activity of the fruit essential oil of Alpinia oxyphylla on six human cancer cell lines

The cytotoxic activity of the Alpinia oxyphylla fruit essential oil may be attributed to specific components of the oil. A few of the compounds found in Alpinia oxyphylla fruit essential oil have been tested for cytotoxic properties. $\alpha$-humulene and $\beta$-caryophyllene have been reported to have strong cytotoxicity $^{7,8}$. Caryophyllene oxide is also known to possess modest cytotoxic activity ${ }^{7}$. Apart from that, studies on terpinen-4-ol showed that it can induce apoptosis in human melanoma cells ${ }^{6}$. However, the relatively low concentration of $\alpha$-humulene $(0.49$ $\mathrm{g} / 100 \mathrm{~g}), \beta$-caryophyllene $(5.56 \mathrm{~g} / 100 \mathrm{~g})$, caryophyllene oxide $(2.11 \mathrm{~g} / 100 \mathrm{~g})$ and terpinen-4-ol $(0.42 \mathrm{~g} / 100 \mathrm{~g})$ cannot fully explain the potent cytotoxic activity of the Alpinia oxyphylla fruit essential oil. In fact, it has been reported that sesquiterpenes are responsible for the cytotoxic activity of Myrica gale L. essential oil ${ }^{9}$, which means some other compounds, probably sesquiterpenes and/or oxygenated sesquiterpenes are active in the essential oil. In addition, minor components could also contribute to cytotoxic activity of the oil. It is also possible that the minor components may be involved in some type of synergism with the other active compounds.
Antioxidant activity: Antioxidant activity of the essential oil of Alpinia oxyphylla has been determined by two different test systems namely $\mathrm{DPPH}^{\circ}$ and reducing power assay.

The $\mathrm{DPPH}^{\bullet}$ radical scavenging assay is commonly employed in evaluating the ability of antioxidants to scavenge free radicals. $\mathrm{DPPH}^{\bullet}$ is a stable free radical (deep violet colour) and accepts an electron or hydrogen radical to become a stable diamagnetic molecule with discolouration. The degree of discolouration indicates the free radical scavenging potentials of the sample/antioxidant. As can be seen from Table-3, the essential oil presented a good radical scavenging activity in dose-dependent increase manner at concentrations ranging from $50-400 \mu \mathrm{g} / \mathrm{mL}$. The value for $50 \%$ scavenging $\left(\mathrm{IC}_{50}\right)$ of the essential oil was found to be $140.7 \mu \mathrm{g} / \mathrm{mL}$. However, the activity of the oil was less than that of the positive control, BHT $\left(\mathrm{IC}_{50}: 21.6 \mu \mathrm{g} / \mathrm{mL}\right.$ ), a well known free radical scavenger. Literature survey revealed that $\alpha$-pinene ${ }^{1}, \gamma$-terpinene ${ }^{12}$ and $\beta$-caryophyllene ${ }^{10}$ possess free radical scavenging activity using the same DPPH assay. Furthermore, some essential oils rich in non-phenolic compounds also exhibited antioxidant potentials ${ }^{11}$. Similarly, the essential oil of Alpinia oxyphylla is markedly rich in non-phenolic components (Table-1). Therefore, antioxidant activity of the essential oil might be attributed to the non-phenolic constituents.

\begin{tabular}{cc} 
TABLE-3 \\
DPPH. RADICAL SCAVENGING ACTIVITY OF \\
THE FRUIT ESSENTIAL OIL OF Alpinia oxyphylla \\
\hline Essential oil & Scavenging activity $(\%)^{\mathrm{a}}$ \\
concentration $(\mu \mathrm{g} / \mathrm{mL})$ & $27.1 \pm 0.4$ \\
\hline 50 & $32.4 \pm 1.2$ \\
100 & $68.2 \pm 0.2$ \\
200 & $89.8 \pm 1.2$ \\
400 & $140.7 \pm 1.6$ \\
$\mathrm{IC}_{50}$ of oil $(\mu \mathrm{g} / \mathrm{mL})$ & $21.6 \pm 2.0$ \\
$\mathrm{IC}_{50}$ of BHT $(\mu \mathrm{g} / \mathrm{mL})$ & \\
\hline${ }^{\mathrm{a}}$ Results are means $\pm \mathrm{SD}$ of three independent experiments
\end{tabular}

In reducing power assay, potential antioxidants reduce the $\mathrm{Fe}^{3+} /$ ferricyanide complex to its ferrous form which can be monitored spectrometrically at $700 \mathrm{~nm}$. Increased absorbance of the reaction mixture indicates increased reducing power. Fig. 2 showed the dose-response curves for the reducing power of the essential oil of Alpinia oxyphylla and BHT. The reducing power of the oil increased with its increasing concentration. Moreover, the reducing power values were positively correlated with the concentrations of the oil and BHT in the range of $0-500 \mu \mathrm{g} / \mathrm{mL}$. At a concentration of $500 \mu \mathrm{g} / \mathrm{mL}$, the reducing power of the oil was 0.607 , whereas at the same concentration, the value of BHT was 1.557. Although the essential oil showed lower reducing power than BHT, it was evident that the oil has ability to reduce Fe (III) to Fe (II). The reducing activity might be due to the presence of abundant sesquiterpene hydrocarbons and/or oxygenated sesquiterpenes in the essential oil ${ }^{11}$.

\section{Conclusion}

In present study, most components of Alpinia oxyphylla fruit essential oil were identified and their cytotoxic and antioxidant activity were investigated. The results clearly showed 


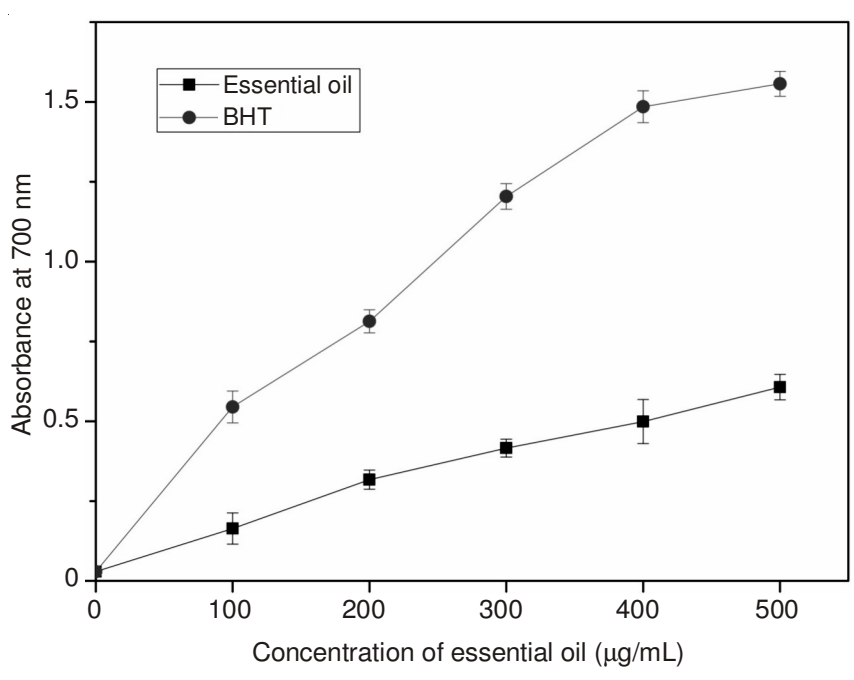

Fig. 2. Reducing power of the fruit essential oil from Alpinia oxyphylla

that the oil presented potent cytotoxic activity against six human cancer cell lines tested. The essential oil also exhibited strong antioxidant activity. These results suggest that Alpinia oxyphylla fruit essential oil could be a potential source for pharmaceuticals. Further studies are needed to find active components and elucidate their anticancer mechanisms.

\section{ACKNOWLEDGEMENTS}

This work was supported by a grant from the Science and Technology Commission of Shanghai Municipality (STCSM; No. 08DZ1974000 and No. 10dz2220500).

\section{REFERENCES}

1. A. Sokmen, M. Sokmen, D. Daferera, M. Polissiou, F. Candan, M. Unlu and A. Akpulat, Phytother. Res., 18, 451 (2004).

2. M. Sokmen, J. Serkedjieva, D. Daferera, M. Gulluce, M. Polissiou, B. Tepe, H.A. Akpulat, F. Sahin and A. Sokmen, J. Agric. Food Chem., 52, 3309 (2004).

3. M.G. Miguel, Molecules, 15, 9252 (2010).

4. C.M. Jardim, G.N. Jham, O.D. Dhingra and M.M. Freire, J. Chem. Ecol., 34, 1213 (2008).

5. M.G. Evandri, L. Battinelli, C. Daniele, S. Mastrangelo, P. Bolle and G. Mazzanti, Food. Chem. Toxicol., 43, 1381 (2005).

6. A. Calcabrini, A. Stringaro, L. Toccacieli, S. Meschini, M. Marra, M. Colone, G. Salvatore, F. Mondello, G. Arancia and A. Molinari, J. Invest. Dermatol., 122, 349 (2004).
7. S. Sibanda, G. Chigwada, M. Poole, E.T. Gwebu, J.A. Noletto, J.M. Schmidt, A.I. Rea and W.N. Setzer, J. Ethnopharmacol., 92, 107 (2004).

8. M. Sylvestre, A. Pichette, A. Longtin, F. Nagau and J. Legault, J. Ethnopharmacol., 103, 99 (2006).

9. M. Sylvestre, J. Legault, D. Dufour and A. Pichette, Phytomedicine, 12, 299 (2005)

10. H.J.D. Dorman, A.C. Figueiredo, J.G. Barroso and S.G. Deans, Flav. Fragr. J., 15, 12 (2000).

11. K.F. EI-Massry, A.H. EI-Ghorab and A. Farouk, Food Chem., 79, 331 (2002).

12. B. Tepe, A. Sihoglu-Tepe, D. Daferera, M. Polissiou and A. Sokmen, Food Chem., 103, 766 (2007).

13. A.E. Edris, Phytother. Res., 21, 308 (2007).

14. Chinese Pharmacopoeia Commission, Pharmacopoeia of the People's Republic of China, China Medical Science and Technology Press, Beijing, vol. 1, p. 274 (2010).

15. O. Muraoka, M. Fujimoto, G. Tanabe, M. Kubo, T. Minematsu, H. Matsuda, T. Morikawa, I. Toguchida and M. Yoshikawa, Bioorg. Med. Chem. Lett., 11, 2217 (2001).

16. T. Morikawa, H. Matsuda, I. Toguchida, K. Ueda and M. Yoshikawa, J. Nat. Prod., 65, 1468 (2002).

17. J.G. Luo, X.Q. Lv, X.B. Wang and L.Y. Kong, Phytochem. Lett., 5, 134 (2012).

18. T.Y. Shin, J.H. Won, H.M. Kim and S.H. Kim, Am. J. Chin. Med., 29, 293 (2001).

19. E. Lee, K.K. Park, J.M. Lee, K.S. Chun, J.Y. Kang, S.S. Lee and Y.J. Surh, Carcinogenesis, 19, 1377 (1998).

20. K.S. Chun, K.K. Park, J. Lee, M. Kang and Y.J. Surh, Oncol. Res., 13, 37 (2001).

21. S. Guan, Y.-M. Bao, B. Jiang and L.J. An, Eur. J. Pharmacol., 538, 73 (2006).

22. Z.J. Zhang, L.C.V. Cheang, M.W. Wang, G.H. Li, I.K. Chu, Z.X. Lin and S.M.Y. Lee, Cell. Mol. Neurobiol., 32, 27 (2012).

23. X.Z. Luo, J.G. Yu, L.Z. Xu, S.L. Yang, J.D. Feng and S.L. Ou, China J. Chin. Mater. Med., 26, 262 (2001).

24. T. Li, Y.Z. Li, C.F. Lu, L.Q. He, Y. Jiang and H.M. Lu, Food Sci. Technol., 35, 301 (2010).

25. R. Costa, M.R. De Fina, M.R. Valentino, A. Rustaiyan, P. Dugo, G. Dugo and L. Mondello, Flav. Fragr. J., 24, 75 (2009).

26. R.P. Adams, Identification of Essential Oil Components by Gas Chromatography/Mass Spectrometry, Allured Publishing Corporation, Carol Stream, IL, USA, edn 4 (2007).

27. C.Z. Wang, Y. Su, D. Li, B. Cai and Y.L. Guo, Anal. Lett., 43, 2297 (2010).

28. A. Monks, D. Scudiero, P. Skehan, R. Shoemaker, K. Paull, D. Vistica, C. Hose, J. Langley, P. Cronise, A. Vaigro-Wolff, M. Gray-Goodrich, H. Campbell, J. Mayo and M. Boyd, J. Natl. Cancer Inst., 83, 757 (1991).

29. A. Shirwaikar, A. Shirwaikar, K. Rajendran and I.S.R. Punitha, Biol. Pharm. Bull., 29, 1906 (2006).

30. M. Oyaizu, Jpn. J. Nutr., 44, 307 (1986). 